\title{
The Views of University Students on Guilt in Turkey
}

\author{
Sevda Aslan \\ University of Kırıkkale, Kırıkkale, Turkey
}

\begin{abstract}
In this study, it is aimed to determine the views of university students on guilt. The study group consisted of 272 students at all levels studying at Ondokuz Mayıs University Faculty of Arts and Sciences, Dokuz Eylul University Faculty of Arts and Sciences, Ahi Evran University Faculty of Arts and Sciences, Karabuk University Faculty of Engineering, and Nigde University Faculty of Economics and Administrative Sciences in Spring semester 2015. There were 155 female students and 117 male students participating in the study. In order to determine the views of university students, guilt form "University Students' Views on Guilt" was developed by the researcher. Each form consisted of 10 open-ended questions related to the students' views about guilt. The answers given to the 10 open-ended questions were combined and gathered under common headers. This is a descriptive study. The results of this study find that the opinions of university students on guilt include criminal actions in learned, especially from family, friends, and so on, and aggressive thoughts due to family insufficient, the characteristics nurtured by which can be easily hurt.
\end{abstract}

Keywords: university students, guilt, student views

\section{Introduction}

Infants are not good or bad. They are simply beings that are in interaction with their environment and undergoing constant growth. It is their experiences that make them good or bad. Crime, on the one hand, refers to the act that takes place in the public sphere and violates certain rules or laws, and as a result, is met with legitimate punishment and the intervention of the public authorities. Crime, on the other hand, is a social problem (Öztürk Çopur, Ulutaşdemir, \& Balsak, 2015). Criminality results from a conflict that pits the individual against other members of the society. Factors that lead adolescents to crime can be divided into two main categories: Individual factors and environmental factors. Individual factors explain only a small proportion of the crimes committed by adolescents. The major environmental factors that lead adolescents to crime are family, school, workplace, city, and peers (Gültekin Akduman, Akduman, \& Cantürk, 2007). Guilt is the result of the interaction between the individual and her/his environment. To eliminate feelings of guilt, its causes should first be removed (Küçük \& Acet, 2002). Moreover, it is known that, during adolescence period, some personality structures are challenged more compared with the other periods, which gives rise to the disintegration of personality structures that is difficult to recover. The cases of committing crimes or suicide, and the bouts of mental illnesses are often observed during this period, and they are considered as unhealthy ways to cope with internal and external strains caused by unhealthy and insecure personality structures (Kıliçc1, 2000).

Sevda Aslan, Dr., associate professor, Department of Educational Sciences Psychological Counselling and Guidance, University of Kırıkkale. 


\section{Literature Review}

In a review of studies conducted on guilt, Köksal and Gençdoğan (2007) found that there were no significant differences between university students with and without depression in terms of feelings of guilt and shame. The authors found that concepts of guilt and shame were related. They also found that girls experienced feelings of guilt and shame more frequently than boys. In a survey of university students, Erden and Akbaş (2015) found that an increased sense of guilt was associated with higher levels of compatability and responsibility. They found that the personality trait of compatability was a positive predictor of feelings of guilt for both sexes, but the personality trait of responsibility was a predictor of feelings of guilt only among men. Emir Öksüz and Bilge (2014) found that levels of feelings of guilt and shame among university students were not significant predictors of suicidal tendencies. Sankır (2014) found that high self-esteem among 11th grade high school students inhibited deviant and criminal behavior, whereas low self-esteem accelerated and facilitated engaging in deviant or criminal behavior. Aslan (2015) found that the most positive perception of the relationship between parents and high school students who are crime-prone and pushed to commit crimes is that families trust these students in their drive to make the most suitable decision, develop the most appropriate concept and the most proper behaviour about themselves among other choices, and therefore select the most appropriate motive. The other perception is that, when families are concerned about their academic success and when these students are far away from home, families believe these students make the appropriate move.

From another perspective, Karasu (2008) found that more crimes are committed in highly urbanized and economically developed cities that have a high share of the GDP (Gross Domestic Product), and high population densities and net migration. Ayar and Öztürk (2015) found that master's theses in Turkey identified urbanization and socio-economic factors as the causes of juvenile delinquency, and Ph.D. dissertations identified social circumstances, cases of child abuse, and school-related factors amongst the causes. Sığrı, Tabak, and Sağır (2010) found that the dominant feeling among women was shame, whereas the dominant feeling among men was guilt. Özen and Sümer (2013), in their study on married couples, identified three dimensions of expressing guilt: apology/compromise, denial, and explanation. In conclusion, crime is one of the biggest obstacles to social development. In this light, this study aims to identify the opinions of university students on guilt.

\section{Method}

The studies aiming to define a situation, which already exists or existed in the past, are studies designed according to scanning model (Karasar, 2003). In this study, an existing situation was analysed since the study aimed to determine the views of university students on guilt. Therefore, this study is a patterned research designed according to scanning model.

\section{Participants}

In this study, it is aimed to determine the views of university students on guilt. The study group consisted of 272 students at all levels studying at Ondokuz May1s University Faculty of Arts and Sciences, Dokuz Eylul University Faculty of Arts and Sciences, Ahi Evran University Faculty of Arts and Sciences, Karabuk University Faculty of Engineering, and Nigde University Faculty of Economics and Administrative Sciences in Spring semester 2015. The number of female students participating in the study was $155(56.99 \%)$ and the number of male students participating in the study was 117 (43.01\%). 


\section{Research Insturment}

The guilt form "University Students' Views on Guilt" was developed in order to determine the views of university students on guilt. Each form consisted of 10 open-ended questions to determine their views about guilt.

\section{The Analysis of the Data}

The answers given to the 10 open-ended questions in the form were combined and gathered under common headers. Frequencies and percentages were calculated.

\section{Results}

\section{Results on University Students' Perception of Guilt}

In this section, you can see the frequency $(n)$ and percentage (\%) distributions according to the answers given to the items in the "University Students' Views on Guilt."

Table 1

Distribution of Frequencies (n) and Percentages (\%) of Student Opinions on the Characteristics to Facilitate the Emergence of Guilt Behavior Features

\begin{tabular}{lll}
\hline Opinions & Frequency $(n)$ & Percentage (\%) \\
\hline Social class conflict & 70 & 25.74 \\
High unemployment rate & 64 & 23.53 \\
Migration from the village to the city & 55 & 20.22 \\
Poverty & 48 & 17.65 \\
Belong to subcultures & 35 & 12.86 \\
\hline
\end{tabular}

As seen in Table 1, 25.74\% of the students mentioned "social class conflict" as the most important personal chracateristics, whereas $12.86 \%$ of the students mentioned "belong to subcultures" as the least important characteristics.

Table 2

Distribution of Frequencies (n) and Percentages (\%) of Student Opinions on the Characteristics to Complicate the Processing of Crime

\begin{tabular}{lll}
\hline Opinions & Frequency $(n)$ & Percentage (\%) \\
\hline Security cameras & 104 & 38.24 \\
Preventive patrol services & 77 & 28.31 \\
Private security staff and systems & 63 & 23.16 \\
Physical environment regulations & 28 & 10.29 \\
\hline
\end{tabular}

As seen in Table 2, 38.24\% of the students mentioned "security cameras" as the most important personal chracateristics, whereas $10.29 \%$ of the students mentioned "physical environment regulations" as the least important characteristics.

As seen in Table 3, 59.19\% of the students mentioned "criminal actions in learned, especially from family, friends, and so on" as the most important personal chracateristics, whereas $40.81 \%$ of the students mentioned "criminal behavior learned in relationships with other individuals in the interaction process" as the least important characteristics. 
Table 3

Distribution of Frequencies (n) and Percentages (\%) of Student Opinions on the Process to an Individual's Criminal Behavior

\begin{tabular}{lcc}
\hline Opinions & Frequency $(n)$ & Percentage $(\%)$ \\
\hline Criminal actions in learned, especially from family, friends, and so on. & 161 & 59.19 \\
Criminal behavior learned in relationships with other individuals in the interaction process. & 111 & 40.81 \\
\hline
\end{tabular}

Table 4

Distribution of Frequencies (n) and Percentages (\%) of Student Opinions on Self-Harm Behavior Showing Youths of Family Features

\begin{tabular}{lll}
\hline Opinions & Frequency $(n)$ & Percentage $(\%)$ \\
\hline Family insufficient, the characteristics nurtured by which can be easily hurt. & 136 & 50 \\
Having conflicted marital relationships. & 136 & 50 \\
\hline
\end{tabular}

As seen in Table 4, 50\% of the students mentioned "family insufficient, the characteristics of which can be easily hurt" as the most important personal chracateristics, whereas $50 \%$ of the students mentioned "having conflicted marital relationships" as the least important characteristics.

Table 5

Distribution of Frequencies (n) and Percentages (\%) of Student Opinions on Overcoming Feelings of Guilt

\begin{tabular}{lll}
\hline Opinions & Frequency $(n)$ & Percentage $(\%)$ \\
\hline Build positive relationships with others. & 98 & 36.03 \\
To understand the feelings of empathy towards making. & 88 & 32.35 \\
Strives to eliminate the negative status. & 86 & 31.62 \\
\hline
\end{tabular}

As seen in Table 5,36.03\% of the students mentioned "build positive relationships with others" as the most important personal chracateristics, whereas $31.62 \%$ of the students mentioned "strives to eliminate the negative status" as the least important characteristics.

Table 6

Distribution of Frequencies (n) and Percentages (\%) of Student Opinions on Relation Between Education Level and Crime Behavior

\begin{tabular}{lll}
\hline Opinions & Frequency $(n)$ & Percentage $(\%)$ \\
\hline Train to influence the behavior of individuals and relationships. & 92 & 33.82 \\
Create humane and rational solution to the problems of education. & 90 & 33.09 \\
To create awareness in people's education. & 90 & 33.09 \\
\hline
\end{tabular}

As seen in Table 6, 33.82\% of the students mentioned "train to influence the behavior of individuals and relationships" as the most important personal chracateristics, whereas $33.09 \%$ of the students mentioned "to create awareness in people's education" as the least important characteristics.

As seen in Table 7, 34.93\% of the students mentioned "the low education level of the parents" as the most important personal chracateristics, whereas $17.28 \%$ of the students mentioned "divorce of parents" as the least important characteristics.

As seen in Table 8, 37.87\% of the students mentioned "to eliminate the factors driving the trends in the crime of child" as the most important personal chracateristics, whereas $6.98 \%$ of the students mentioned "criminals and modify child support" as the least important characteristics. 
Table 7

Distribution of Frequencies (n) and Percentages (\%) of Student Opinions on the Reason to the Criminal Behavior of Individuals

\begin{tabular}{lll}
\hline Opinions & Frequency $(n)$ & Percentage $(\%)$ \\
\hline The low education level of the parents & 95 & 34.93 \\
Poverty & 66 & 24.26 \\
Parental unemployment & 64 & 23.53 \\
Divorce of parents & 47 & 17.28 \\
\hline
\end{tabular}

Table 8

Distribution of Frequencies (n) and Percentages (\%) of Student Opinions on Criminals Children's Reintegration

\begin{tabular}{lcc}
\hline Opinions & Frequency $(n)$ & Percentage $(\%)$ \\
\hline To eliminate the factors driving the trends in the crime of child & 103 & 37.87 \\
To help society adapt to changing conditions & 81 & 29.78 \\
To guarantee the rights of the child & 69 & 25.37 \\
Criminals and modify child support & 19 & 6.98 \\
\hline
\end{tabular}

Table 9

Distribution of Frequencies (n) and Percentages(\%) of Student Opinions on Parental Attitudes in the Emergence of Guilt Feelings in Children

\begin{tabular}{lll}
\hline Opinions & Frequency $(n)$ & Percentage $(\%)$ \\
\hline Repressive attitude of parents & 100 & 36.76 \\
The punitive attitude of parents & 68 & 25 \\
The admonishment attitude of parents & 67 & 24.63 \\
Extremely intimidating attitude of the parents & 37 & 13.61 \\
\hline
\end{tabular}

As seen in Table 9, 36.76\% of the students mentioned "repressive attitude of parents" as the most important personal chracateristics, whereas $13.61 \%$ of the students mentioned "extremely intimidating attitude of the parents" as the least important characteristics.

Table 10

Distribution of Frequencies (n) and Percentages (\%) of Student Opinions on Causes of Juvenile Delinquency

\begin{tabular}{lll}
\hline Opinions & Frequency $(n)$ & Percentage $(\%)$ \\
\hline Aggressive thoughts & 141 & 51.84 \\
Emotional arousal & 131 & 48.16 \\
\hline
\end{tabular}

As seen in Table 10, 51.84\% of the students mentioned "aggressive thoughts" as the most important personal chracateristics, whereas $48.16 \%$ of the students mentioned "emotional arousal" as the least important characteristics.

\section{Discussion}

Reasons for resorting to guilt as listed according to the opinions of university students are as follows, according to priority: criminal actions in learned, especially from family, friends, and so on (161); aggressive thoughts (141); family insufficient, the characteristics nurtured by which can be easily hurt (136); security cameras (104); to eliminate the factors driving the trends in the crime of child (103); repressive attitude of parents (100); build positive relationships with others (98); the low education level of the parents (95); train to 
influence the behavior of individuals and relationships (92); and social class conflict (70). In the development and socialization of the individual, factors, such as structural characteristics of the family in which they were born and raised, whether the family performs its functions, and intra-family conflict, can all play a role in leading individuals to crime. The socioeconomic conditions of the family, social environment, and individual, genetic, and psychological factors also have an indirect effect on crime. A review of the literature shows that many children who commit crimes coming from broken homes, due to reasons, such as death, divorce or abandonment, having many siblings_-with an average number of five children in the family, or were separated from their families while growing up. Children who commit crimes usually have other people in their families or in their immediate social environment who were involved in crime. One of the most important factors leading children to commit crimes is being the victim of intra-family violence, negligence, or abuse. It is also argued that children with parents who have low levels of education are more at risk of getting involved in crime. Poor communication among parents or between parents and children is also a factor leading children to commit crimes (Acar, Demir, Görmez, \& Keser, 2015). The findings of this study are parallel with those of Acar et al. (2015) and Gültekin Akduman, Akduman, and Cantürk (2007).

\section{Conclusion and Recommendation}

In conclusion, family plays an important role in preventing criminal behavior in childhood. Aggression in family and among friends may encourage crime. Positive relationships should be established to prevent criminal tendencies, parents should be better educated to eliminate abusive behavior, and steps should be taken to avoid conflict between the individual and the society, improve children's social integration, and help social development. In light of these findings, the following recommendations are made: Families should be provided crime prevention guidance that fits their biological, psychological, and social characteristics. In addition, efforts should be made to raise awareness among children concerning the concept of crime.

\section{References}

Acar, G., Demir, A., Görmez, D., \& Keser, I. (2015). Aile ve çocuk suçluluğu ilişkisi (Family and juvenile delinquency relationship). Hacettepe Üniversitesi Sağlık Bilimleri Fakültesi (Hacettepe University Faculty of Health Sciences Journal), 1(12), 651-656.

Aslan, S. (2015). Suça eğilimi olan lise öğrencilerinin ailelerine ilişkin algıları (The perceptions of tendency to crime's high school students regarding their family). Erzincan Üniversitesi Eğitim Fakültesi Dergisi (Erzincan University Journal of the Faculty of Education), 17(1), 282-294.

Ayar, D., \& Öztürk, C. (2015). Türkiye'de lisansüstü çalışmalarda çocuk suçluluğu (Juvenile delinquency in post graduate studies in Turkey). The Journal of Pediatric Research, 2, 17-20.

Emir Öksüz, E., \& Bilge, F. (2014). Üniversite öğrencilerinin intihar olasılıklarının incelenmesi (Examining the suicide probabaility among university students). Eğitim ve Bilim (Education and Science), 39(171), 407-420.

Erden, S., \& Akbağ, M. (2015). How do personality traits effect shame and guilt? An evaluation of the Turkish culture. Eurasian Journal of Educational Research, 58, 113-132. Retrieved May 5, 2015, from http://dx.doi.org/10.14689/ejer.2015.58.4

Gültekin Akduman, G., Akduman, B., \& Cantürk, G. (2007). Ergen suçluluğunda bazı kişisel ve ailesel özelliklerin incelenmesi (Investigation of the some personal and familial characteristics of juvenile deliquency). Türk Pediatri Arşivi (Turkish Archives of Pediatrics), 42, 156-161.

Karasar, N. (2003). Bilimsel araştırma yöntemi-kavramlar, ilkeler, teknikler (12. Bask1.) (Scientific research method-concepts, principles, technique [12th ed.]). Ankara: Nobel.

Karasu, M. A. (2008). Türkiye'de kentleşme dinamiklerinin suça etkisi (The effect of Turkey's urbanization dynamics on crime). Ankara Üniversitesi Hukuk Fakültesi Dergisi (Ankara University Journal of Law Faculty), 57(4), 255-281.

Kılıçc1, Y. (2000). Okulda ruh sağlı̆̆ (Mental health in school). Ankara: Anı Yayıncılık. 
Köksal, F., \& Gençdoğan, B. (2007). Depresif olanlar ile olmayanların suçluluk, utanç ve öfke tarzlarının incelenmesi (Depressive and non-depressive ones, examining their guilt, shame, and anger). Atatürk Üniversitesi Sosyal Bilimler Enstitüsü Dergisi (Journal of Graduate School of Social Sciences), 9(1), 163-175.

Küçük, V., \& Acet, M. (2002). Bir kişilik özelliği olarak suçluluk ve sporla ilişkisi (Guilt and sports relations as a personality trait). Dumlupınar Üniversitesi Sosyal Bilimler Dergisi (Dumlupınar University Social Science Journal), 7, 369-375.

Özen, A., \& Sümer, N. (2013). Evlilikte kızgınlık, üzüntü ve suçluluk duygularının ifade biçimlerinin ölçümü (Marriage anger, sadness, and measuring the expression of guilt). Türk Psikoloji Yazılarl (Turkish Psychological Articles), 16(31), 36-55.

Öztürk Çopur, E., Ulutaşdemir, N., \& Balsak, H. (2015). Çocuk ve suç (Child and guilt). Hacettepe Üniversitesi Sağlık Bilimleri Fakültesi (Hacettepe University Faculty of Health Sciences Journal), 1(2), 120-124.

Sankır, H. (2014). Gençlerin sapmış ve suçlu davranışlara yönelmelerinde benlik saygısının etkisi: Lise 11.sınıf örneği (Influence of self esteem on youths who tend to involve deliquent and deviant behaviors: Case study among 11th grade students). Turkish Studies International Periodical for the Languages, Literature and History of Turkish or Turkic, 9(2), 1311-1333.

Sığrı, Ü., Tabak, A., \& Sağır, A. (2010). Çalışanlarda suçluluk ve utanç duygusunun cinsiyet-yaş durumuna göre mukayesesi ve örgütlerde utanç yönetiminin kullanılması (A comparison of guilt and shame emotions of workers in terms of gender-age differences and "shame managment" in organizations). Cumhuriyet Üniversitesi İktisadi ve İdari Bilimler Dergisi (Cumhuriyet University Journal of Economics and Administrative Sciences), 11(1), 71-85. 